International Journal of Engineering \& Technology, $7(4.20)(2018) 271-276$
International Journal of Engineering \& Technology
SPC
Website: www.sciencepubco.com/index.php/IJET
Research paper

\title{
Study of the Local Scour Around L-Shape Groynes in Clear Water Conditions
}

\author{
Saleh I. Khassaf ${ }^{1 *}$, Hiba A. Abbas ${ }^{2}$ \\ ${ }^{1}$ University of Basrah, College of Engineering, Iraq \\ ${ }^{2}$ University of Kufa, College of Engineering, Iraq \\ *E-mail: salehissakh@gmail.com
}

\begin{abstract}
River training structures; such as groynes; are efficient engineered methods utilized to protect eroding river banks. But during groynes design stage; the designers faces one of the most significant issues which is the evaluation of the maximum depth of local scour around groynes. This is due to the flow area constriction in the groyne location itself; which in turn cause increasing in local velocity that consequently causes the scour. In the present study, the maximum scour depth around L-shape groyne was computed based on laboratory experiments where different number of groynes and distances between them were used as sort of countermeasures to reduce the scour around the groynes foundations. The results showed clear decreasing in scour depth at increasing number of groynes and also distance between them in the limitation of this study. A new formula based on experimental data was derived to calculate the local scour depth. This formula gave $\mathrm{R}^{2}=0.903$ which reflecting good agreement to the results.
\end{abstract}

Keywords: Clear water conditions, L-shape groynes, local scour, river training structures, sediment transport.

\section{Introduction}

The human kind existence is highly related to rivers, which they need to be controlled and trained to get the human life requirements and the optimum use of them. The controlling process usually done by constructing river training structures. Groynes are the most popular and useful transverse river training structures [1] that are defined as a manmade hydraulic structures protruding from the river bank for many purposes such as: bank protection from erosion, maintaining a desired cross section and alignment of rivers by stabilizing them, providing a sufficient flow depth for navigation, enhancement riverine aquatic habitats, modulation the surrounding scenery and facilitating the river accessibility [6].

In spite of the many advantages of groynes; but their existence (or any obstruction placed in alluvial river) lead to development of dangerous scour holes around them, so the groynes will suffer from instability that causing, with time, a failure in the groyne structure. With regard to the local scour, it is important to state that the presence of groynes will trigger a complex system of vortices at the base of the groynes themselves which consider along with the downflow at the upstream face the primal reasons of scour [4], see Fig. 1 where it also shows how the horse-shoe vortex hits the sand bed instantly in front of the groyne and then kicking up the eroded material which subsequently transported downstream by the main flow. The scour holes develop until reaching to its final shape through four sequent phases that are: the initiation phase, the development phase, the stabilization phase and at the last the equilibrium phase. This drifting from phase to another with time depends on the conditions of the flow.

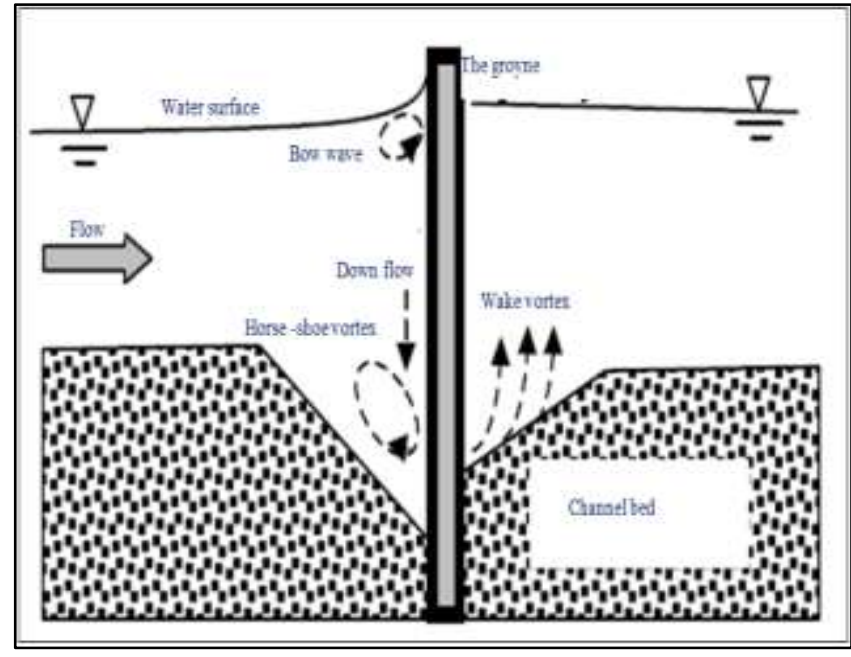

Fig. 1: Flow and local scour at the longitudinal section passing the groyne head [10]

If the flow velocity less than the critical velocity $(\mathrm{V}<\mathrm{Vc})$ (clear water condition), the scour develops first rapidly and then continue until the scour hole dimensions no longer increase and the scour depth reaches a distinctive value that is the maximum depth of scour [9], whereas the scour of live bed takes place if there is general transition of material of bed by the flow and the approach flow velocity becomes greater than the threshold of motion $(\mathrm{V}>\mathrm{Vc})$ [8]. Then the scour hole depth is reached much quickly but oscillates with time since the sediments enters from upstream, then leaves the scour hole, see Fig. 2. 


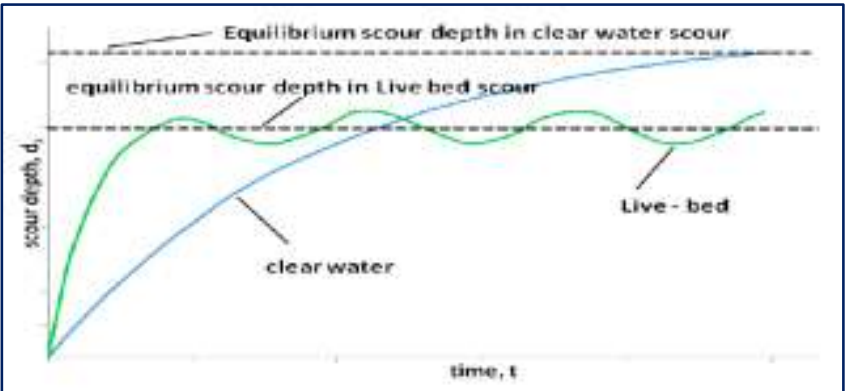

Fig. 2: Conditions of live-bed and clear-water scour [3]

The goal of the present study is to introduce the number of groynes and the distance between them as a two effective countermeasures in order to reduce the local scour around L-shape groyne that is located at a stipulated location.

\section{Scour parameters}

The scour around groynes is a complex $3 \mathrm{D}$ phenomenon that is influenced by several parameters. These parameters are categorized in four main heading as reported by [2], [7]:

1- Approaching flow parameters: flow depth \& intensity, mean \& shear velocity, distribution of velocity and the roughness of the bed 2- Bed sediment parameters: distribution of the particle size, mass density, soil coherence, repose angle and shape of the particle.

3- Groyne parameters: shape plain view, length, spacing, number and direction of the groyne with respect to the main flow direction. 4- Fluid parameters: kinematic viscosity, gravitational acceleration and the mass density.

\section{The laboratory flumes}

The flume used in this work is illustrated in Fig. 3 and Photo 1. It is made of metal frame with tempered $(8 \mathrm{~mm})$ glass sides and having a length of $7.225 \mathrm{~m}$ with inner section of $0.4^{*} 0.4 \mathrm{~m}$. The flume has three parts; the first part is the inlet tank of $1 \mathrm{~m}$ length with cross section of $0.4 * 0.6 \mathrm{~m}$ and contains two screens to avoid the entering of debris into the flume working section. The second part is the working section which has a length of $5.025 \mathrm{~m}$ and consists of three sections; the first section of length $1 \mathrm{~m}$ consists of sharp crested rectangular weir used to measure flow discharge, the middle section was filled with erodible sand to a depth of $0.1 \mathrm{~m}$ and extends over $3 \mathrm{~m}$. The remaining of first and third section of the working section have a bed surface level of $0.1 \mathrm{~m}$ to match the middle level and this bed made from non-swelling and compressed wood. The last part of the flume is a metal reservoir located at the end of the flume with dimensions of $1.2 * 1 * 0.625 \mathrm{~m}$ for length, width and height, respectively.

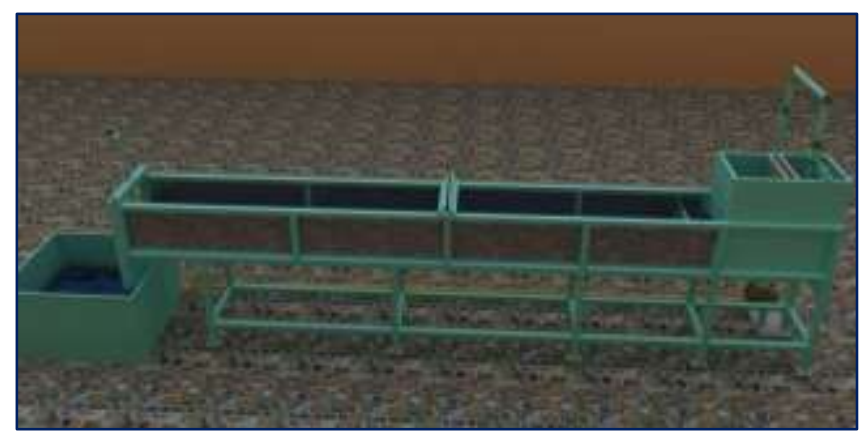

Fig. 3: The laboratory flume (sketched by 3D max program)

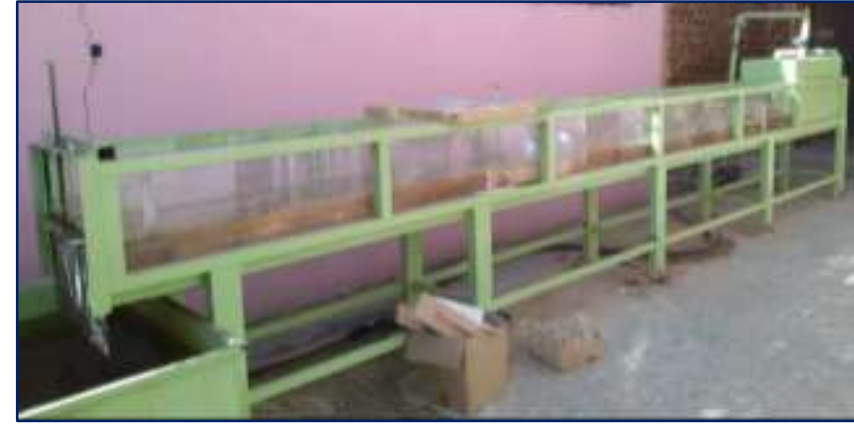

Photo 1: The laboratory flume

The flume has a closed water system where the water is supplied from the reservoir by a pump having specifications of discharge and head equal to $0.833-4.67 \mathrm{l} / \mathrm{sec}$ and $10.5-20.5 \mathrm{~m}$ respectively which located at the flume upstream. The flow depth in the flume is controlled by a tail gate that manually adjustable by means of a hand wheel.

At the end of each test session, the flume is drained carefully and then setting the sand bed to be in a straight level using scraper. To facilitate getting a uniform thickness of the sand layer, two opposite thin wood plates are used where they mounted on the both sides of the flume walls. The scour hole depth measurements are taken using a point gauge consists of a metal bar of $0.4 \mathrm{~m}$ height with a needle its end.

\section{The groyne model}

The model that used in all experiments was L-shape groyne made from $10 \mathrm{~mm}$ thick polystyrene foam material with a net height of $15 \mathrm{~cm}$ and $13 \mathrm{~cm}$ long, see Fig. 4.

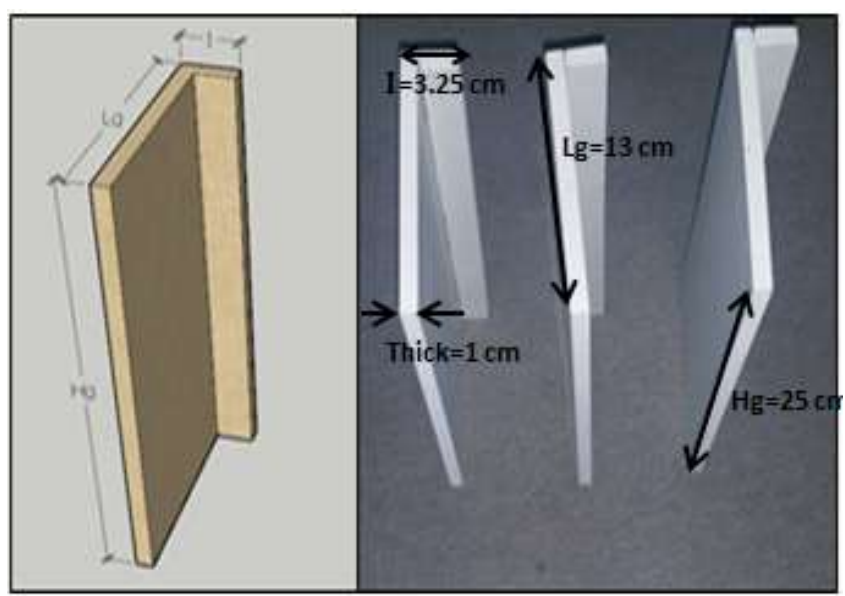

Fig. 4: The L-shape groyne model

The groyne was tested with three different configurations (single, double, triple) and the distances between them were changed three times $(1 \mathrm{~L}, 1.5 \mathrm{~L}, 2 \mathrm{~L})$ to simulate different practical situations and to cover the aim of the present study. The models were fixed vertically in the sand layer and in the middle of the flume working section to achieve a well established flow. A silicon adhesive was used to stick promptly the groynes to the internal side of the flume.

The models material was selected because it does not swell when immersed in water for a long period. A play doh was used to seal the space between the end of the groyne and the flume wall. Photo 2 shows L-shape groyne placed in the flume before beginning the experiments. 


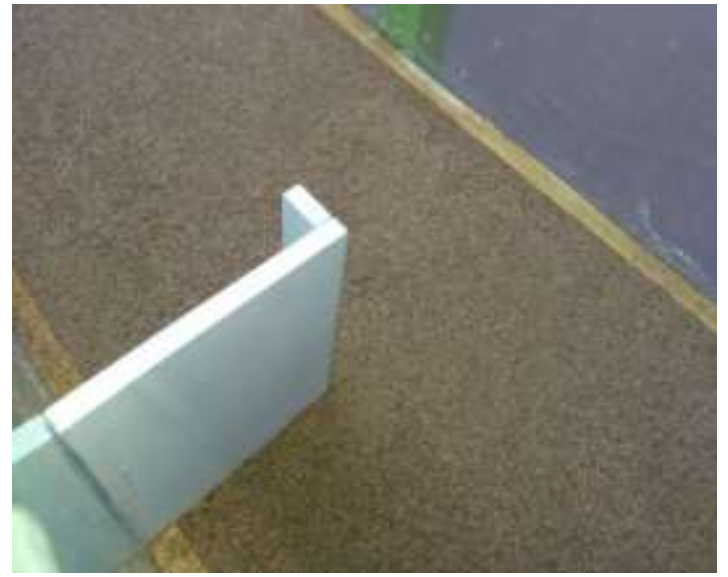

Photo 2: The L-shape groyne placed in the flume

\section{The bed material}

In this study, uniform sand was utilized as the material of flume bed where its characteristics were obtained by a mechanical sieve analysis conducted in the Kufa University at the quality control laboratory.

The result of the grain size distribution showed that the bed material composed of cohesion-less sand with a main diameter $\mathrm{d}_{50}$ equal to $0.7 \mathrm{~mm}$. So the ripple will not be formed since it is only formed if $\mathrm{d}_{50}$ larger than $0.7 \mathrm{~mm}$. Also the geometric standard deviation of the sand size $\sigma_{\mathrm{g}}=\sqrt{ }\left(\mathrm{d}_{84} / \mathrm{d}_{16}\right)$ was equal to 1.31 , so the sand is of uniform size and the results can preclude the sediment non-uniformity effect [5]. Fig. 5 shows the grain size distribution.

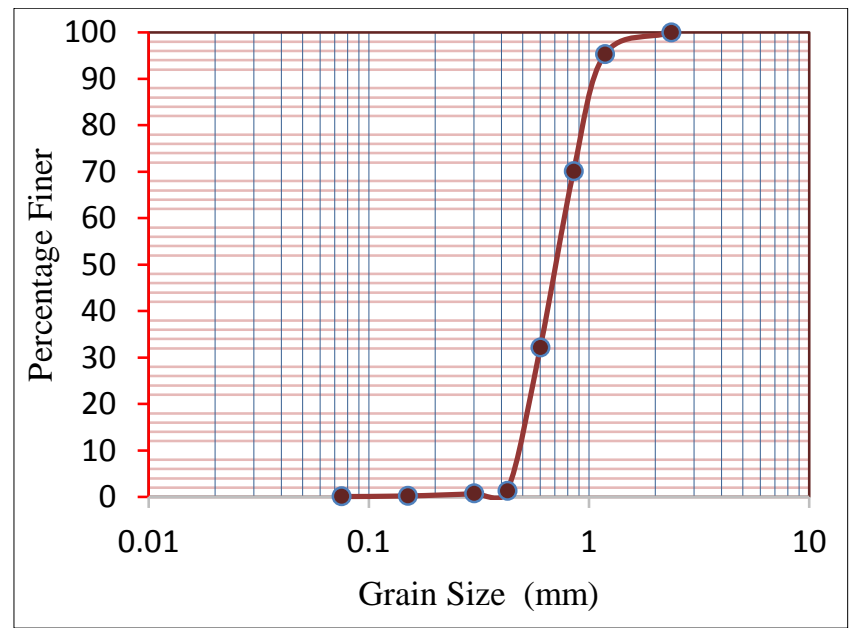

Fig. 5: Grain size distribution for the bed material $\left(d_{50}=0.7 \mathrm{~mm}\right)$

\section{The equilibrium time}

For the purpose of eliminating the time effect; it is required knowing the time to reach the equilibrium conditions of scour. Thus, four different velocities were used and the scour was registered at different time durations using a point gauge to measure the maximum scour at the groyne upstream nose.

The experiments were conducted for 6 hours in order to let the stable conditions to be reached where no more scour will occur with increasing time.

Fig. 6 shows that the scour depth has rapidly increased during the first half of the run period, then it becomes almost constant through the second half. In another meaning, it has been observed that 95$97 \%$ of local scour can be accomplished in 3.5 hours. For more accuracy, a time period of 4 hours has accordingly been used in this study for all experiments.

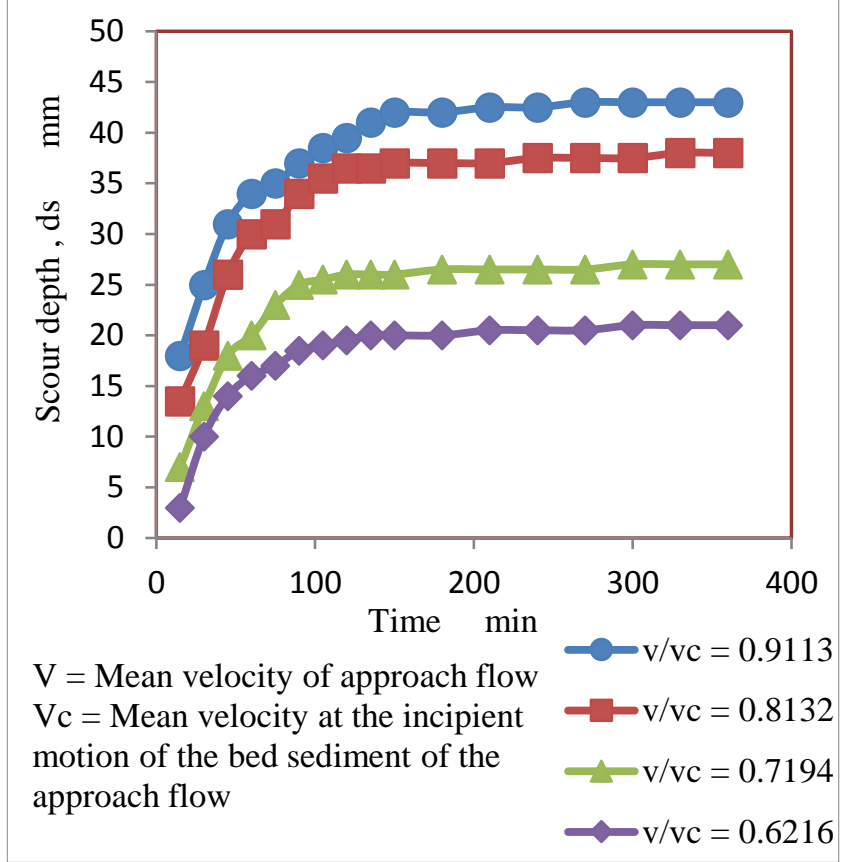

Fig. 6: Scour depth development with the time for L-shape groyne

\section{The experimental work purposes}

A steady subcritical flow and clear water conditions, with zero slope for the flume bed, were the conditions that applied for all the experiments in this study. Table 1 shows the experiments classification according to their purpose.

Fifty six different experiments were conducted to see how the scour depth was affected by the most important parameters which they are: flow depth (y), flow velocity (V), Froude number (Fr), number of groynes (n) and distances between the groynes (b). Table 2 listed all the experimental data.

\begin{tabular}{|c|l|} 
Table 1: The experiments and their purpose \\
\begin{tabular}{|c|l|}
\hline Runs & \multicolumn{1}{c|}{ Description } \\
\hline $1-4$ & $\begin{array}{l}\text { They made for determining the equilibrium time at which the } \\
\text { scour will not increase. }\end{array}$ \\
\hline $1-8$ & $\begin{array}{l}\text { Tested the water depth and the flow velocity using one L- } \\
\text { shape groyne of } 13 \mathrm{~cm} \text { length. }\end{array}$ \\
\hline $9-32$ & $\begin{array}{l}\text { Tested the effect of changing the space between two L-shape } \\
\text { groynes having a length of } 13 \mathrm{~cm} \text { for three times }(\mathrm{L}, 1.5 \mathrm{~L}, 2 \mathrm{~L}) .\end{array}$ \\
\hline $33-56$ & $\begin{array}{l}\text { Tested the effect of changing the space between three L-shape } \\
\text { groynes having a length of } 13 \mathrm{~cm} \text { for three times }(\mathrm{L}, 1.5 \mathrm{~L}, 2 \mathrm{~L}) .\end{array}$ \\
\hline
\end{tabular}
\end{tabular}

\section{Analysis and discussion of results}

The most important step in designing the groynes foundations is evaluating the scour depth formed around them. Therefore, to inspect the scour phenomenon, different sets are carried out using the L-shape groynes.

\subsection{Flow depth (y)}

The effect of flow depth (y) on the scour depth (ds) with different number of groynes is shown in Fig. 7. From this figure, it is very clear that the scour occurrence is directly proportional to the flow depth, where increasing the flow depth will also increase the scour depth while the other influencing parameters are remain constant. 
Table 2: The experimental data

\begin{tabular}{|c|c|c|c|c|c|c|c|c|c|c|}
\hline 直䒴 & $\underset{\partial}{\stackrel{B}{g}}$ & $\begin{array}{l}\text { 湆 } \\
\mathrm{g} \\
>\end{array}$ & $\begin{array}{l}\text { 湆 } \\
\text { : }\end{array}$ & 息 & $=$ & 官 & 5 & 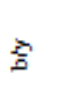 & $\begin{array}{l}\text { 晋 } \\
\text { 要 }\end{array}$ & 혐 \\
\hline 1 & 21 & $0.2 n$ & 0.243 & 0 & 1 & 0.49 & 0.911 & 0 & 43 & 2047 \\
\hline 2 & 21 & 0.198 & 0.243 & 0 & 1 & 0.436 & 0.813 & 0 & 38 & 1.909 \\
\hline 3 & 21 & 0.175 & 0.243 & 0 & 1 & 0.386 & 0.719 & 0 & 27 & 1.286 \\
\hline 4 & 21 & 0.151 & 0.243 & 0 & 1 & 0.333 & 0.621 & 0 & 21 & 1 \\
\hline 5 & 46 & 0.18 & 0.281 & 0 & 1 & 0.268 & 0.640 & 0 & 62 & 1.347 \\
\hline 6 & 36 & 0.18 & 0.27 & 0 & 1 & 0.303 & 0.668 & 0 & 48 & 1.333 \\
\hline 7 & 26 & 0.18 & 0.254 & 0 & 1 & 0.356 & 0.709 & 0 & 34 & 1.307 \\
\hline 8 & 16 & 0.18 & 0.230 & 0 & 1 & 0.454 & 0.790 & 0 & 9 & 0.562 \\
\hline 9 & 21 & $0.2 n$ & 0.243 & 260 & 2 & 0.49 & 0.911 & 12.38 & 30 & 1.428 \\
\hline 10 & 21 & 0.198 & 0.243 & 260 & 2 & 0.436 & 0.813 & 1238 & 26 & 1.238 \\
\hline 11 & 21 & 0.175 & 0.243 & 260 & 2 & 0.396 & 0.719 & 12.38 & 18 & 0.857 \\
\hline 12 & 21 & 0.151 & 0.243 & 260 & 2 & 0,333 & 0.621 & 12.38 & 0 & 0 \\
\hline 13 & 46 & 0.18 & 0.281 & 260 & 2 & 0.268 & 0.640 & 5.65 & 53 & 1.152 \\
\hline 14 & 36 & 0.18 & 0.27 & 260 & 2 & 0.303 & 0.668 & 7.22 & 37 & 1.027 \\
\hline 15 & 26 & 0.18 & 0.254 & 260 & 2 & 0.356 & 0.709 & 10 & 25 & 0.961 \\
\hline 16 & 16 & 0.18 & 0.230 & 260 & 2 & 0.454 & 0.790 & 16.25 & 0 & 0 \\
\hline 17 & 21 & 0.232 & 0.243 & 195 & 2 & 0.49 & 0.911 & 9.29 & 36 & 1714 \\
\hline 18 & 21 & 0.198 & 0.243 & 195 & 2 & 0.436 & 0.813 & 9.29 & 30 & 1.428 \\
\hline 19 & 21 & 0.175 & 0.243 & 195 & 2 & 0.396 & 0.719 & 9.29 & 20 & 0.952 \\
\hline 20 & 21 & 0.151 & 0.243 & 195 & 2 & 0.333 & 0.621 & 9.29 & 2 & 0.095 \\
\hline 21 & 46 & 0.18 & 0.281 & 195 & 2 & 0.268 & 0.640 & 4.24 & 54 & 1.173 \\
\hline 22 & 36 & 0.18 & 0.27 & 195 & 2 & 0.303 & 0.668 & 5.42 & 42 & 1.166 \\
\hline 23 & 26 & 0.18 & 0.254 & 195 & 2 & 0.356 & 0.709 & 75 & 30 & 1.153 \\
\hline 24 & 16 & 0.18 & 0.230 & 195 & 2 & 0.454 & 0.790 & 12.19 & 2 & 0.125 \\
\hline 25 & 21 & $0.2 n$ & 0.243 & 130 & 2 & 0.49 & 0.911 & 6.19 & 38 & 1.909 \\
\hline 26 & 21 & 0.198 & 0.243 & 130 & 2 & 0.436 & 0.813 & 6.19 & 32 & 1523 \\
\hline 27 & 21 & 0.175 & 0.243 & 130 & 2 & 0.396 & 0.719 & 6.19 & 25 & 1.19 \\
\hline 28 & 21 & 0.151 & 0.243 & 130 & 2 & 0.333 & 0.621 & 6.19 & 5 & 0.238 \\
\hline 29 & 46 & 0.18 & 0.281 & 130 & 2 & 0.268 & 0.640 & 2.83 & 55 & 1.195 \\
\hline 30 & 36 & 0.18 & 0.27 & 130 & 2 & 0.303 & 0.668 & 3.61 & 43 & 1.194 \\
\hline 31 & 26 & 0.18 & 0.254 & 130 & 2 & 0.356 & 0.709 & 5 & 30 & 1.153 \\
\hline 32 & 16 & 0.18 & 0.230 & 130 & 2 & 0.454 & 0.790 & 3.13 & 7 & 0.437 \\
\hline 33 & 21 & 0.221 & 0.243 & 260 & 3 & 0.49 & 0.911 & 1238 & 29 & 1381 \\
\hline 34 & 21 & 0.198 & 0.243 & 260 & 3 & 0.436 & 0.813 & 12.38 & 25 & 1.190 \\
\hline 35 & 21 & 0.175 & 0.243 & 260 & 3 & 0.396 & 0.719 & 12.38 & 13 & 0.619 \\
\hline 36 & 21 & 0.151 & 0.243 & 260 & 3 & 0.333 & 0.621 & 12.38 & 0 & 0 \\
\hline 37 & 45 & 0.18 & 0.281 & 260 & 3 & 0.268 & 0.64 & 5.65 & 52 & 1.130 \\
\hline 38 & 36 & 0.18 & 0.27 & 260 & 3 & 0.303 & 0.668 & 7.22 & 32 & 0.558 \\
\hline $\begin{array}{l}9 \\
\end{array}$ & 26 & 0.18 & 0.254 & 260 & $\overline{3}$ & 0.356 & 0.709 & $\overline{10}$ & $\overline{23}$ & 0.854 \\
\hline 40 & 16 & 0.18 & 0.230 & 260 & 3 & 0.454 & 0.790 & 16.25 & 0 & 0 \\
\hline 41 & 21 & 0.222 & 0.243 & 195 & 3 & 0.49 & 0.911 & 9.29 & 31 & 1.476 \\
\hline 42 & 21 & 0.198 & 0.243 & 195 & 3 & 0.436 & 0.813 & 9.29 & 26 & 1.238 \\
\hline 43 & 21 & 0.175 & 0.243 & 195 & 3 & 0.396 & 0.719 & 9.29 & 15 & 0.714 \\
\hline 44 & 21 & 0.151 & 0.243 & 195 & 3 & 0.333 & 0.621 & 9.29 & 0 & 0 \\
\hline 45 & 46 & 0.18 & 0.281 & 195 & 3 & 0.268 & 0.640 & 4.24 & 53 & 1.152 \\
\hline 46 & 36 & 0.18 & 0.27 & 195 & 3 & 0.303 & 0.668 & 5.42 & 34 & 0.944 \\
\hline 47 & 26 & 0.18 & 0.254 & 195 & 3 & 0.356 & 0.709 & 7.5 & 24 & 0.923 \\
\hline 48 & 16 & 0.18 & 0.230 & 195 & 3 & 0.454 & 0.790 & 12.19 & 0 & 0 \\
\hline 49 & 21 & 0.222 & 0.243 & 130 & 3 & 0.49 & 0.911 & 6.19 & 32 & 1.523 \\
\hline 50 & 21 & 0.198 & 0.243 & 130 & 3 & 0.436 & 0.313 & 6.19 & 27 & 1.296 \\
\hline 51 & 21 & 0.175 & 0.243 & 130 & 3 & 0.396 & 0.719 & 6.19 & 18 & 0.857 \\
\hline 52 & 21 & 0.151 & 0.243 & 130 & 3 & 0.333 & 0.621 & 6.19 & 0 & 0 \\
\hline 53 & 46 & 0.18 & 0.281 & 130 & 3 & 0.268 & 0.640 & 283 & 54 & 1.173 \\
\hline 54 & 36 & 0.18 & 0.27 & 130 & 3 & 0.303 & 0.668 & 3.61 & 37 & 1.027 \\
\hline 55 & 26 & 0.18 & 0.254 & 130 & 3 & 0.356 & 0.709 & 5 & 26 & 1 \\
\hline 56 & 16 & 0.18 & 0.230 & 130 & 3 & 0.454 & 0.750 & 3.13 & 0 & 0 \\
\hline
\end{tabular}

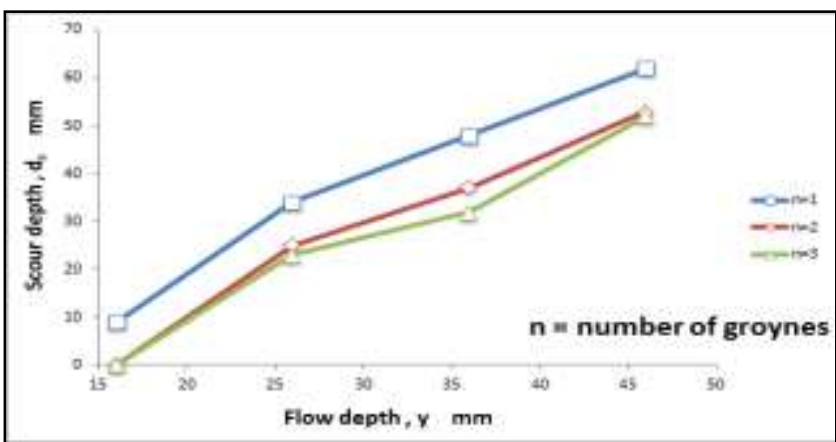

Fig. 7: Effect of flow depth on scour depth development

\subsection{Flow velocity (V)}

A linear increase to the scour depth as the velocity increase was observed for the velocities less than the threshold value, regardless the other parameters. Fig. 8 and photo 3 show the above result which is in agreement with the previous investigations for clear water conditions [1],[3].

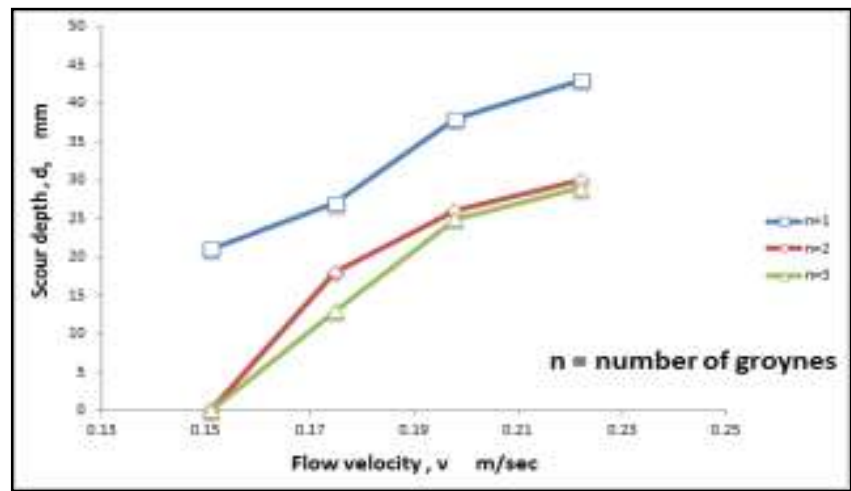

Fig. 8: Effect of flow velocity on scour depth development

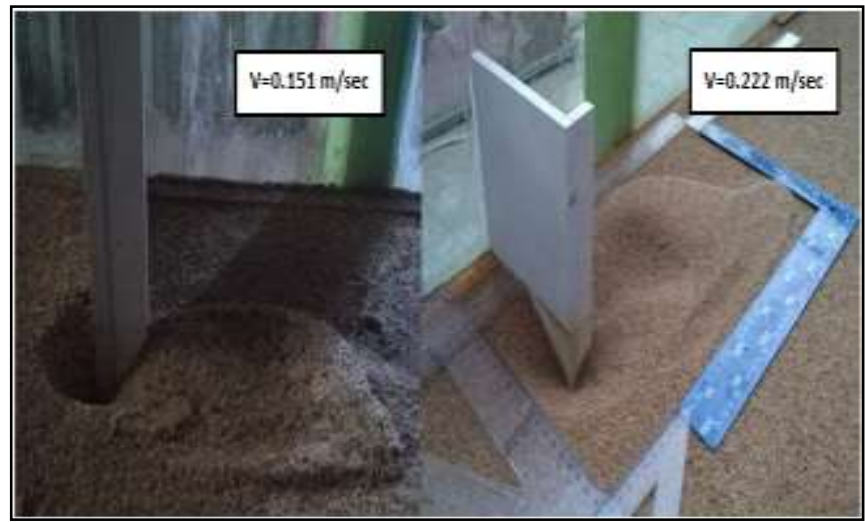

Photo 3: Effect of (V) on (ds) developmen

\subsection{Froude number (Fr)}

The result of the L-shape groyne has been drawn in Fig. 9 to relate Fr with the dimensionless fraction (ds/y). It is clearly evident that any increase in Fr will increase the scour depth at surely constant value for the other parameters.

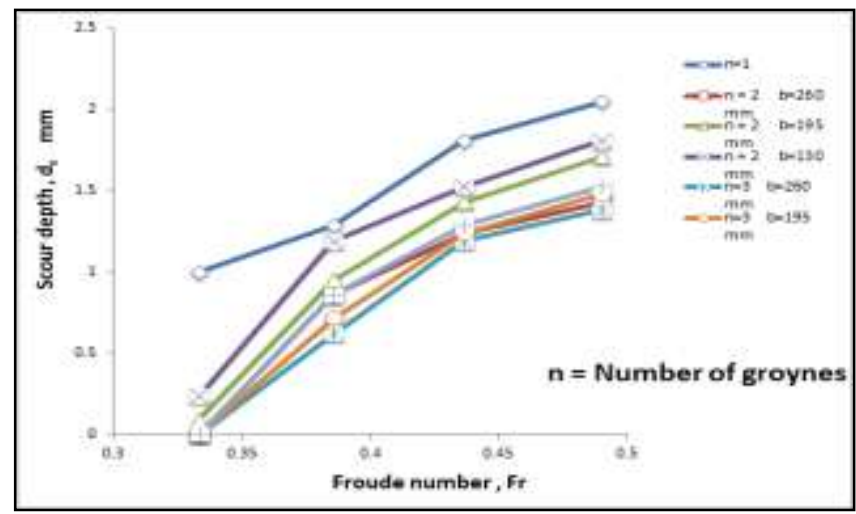

Fig. 9: Effect of Froude number on scour depth development

\subsection{Number of groynes (n)}

The number of groynes has a pivotal impact on the scour process. Fig. 10 shows the decreasing in the scour depth at increasing number of groynes (within the limitation of this study) when the efficiency of the remaining parameters are kept constant. Increasing number of groynes by one will decreasing the scour depth by about $3.33-30.2 \%$. From the experimental observations, the scour area has 
wider range and much deeper elevation for one groyne as compared with that of double or triple groynes.

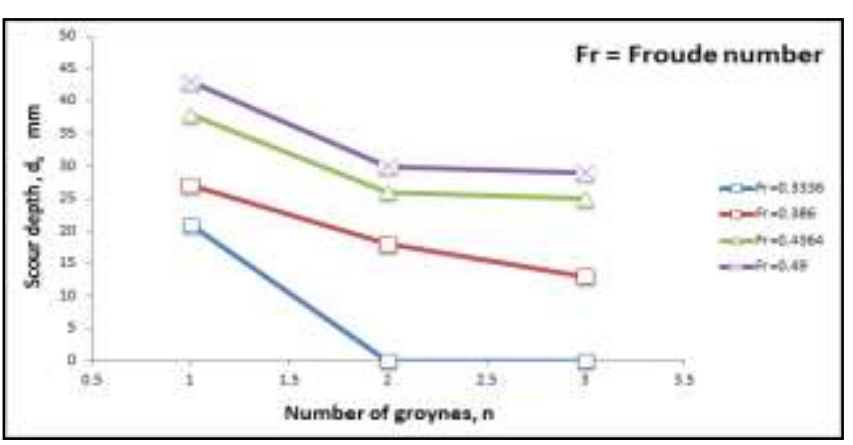

Fig. 10: Effect of groyne number on scour depth development

\subsection{Distances between groynes}

Double and triple groynes configurations were utilized along with three various distances between them to show their effectiveness on the scour depth. The relationship between the distances and the scour depth has been drawn in Fig. 11 and illustrated in Photo 4.

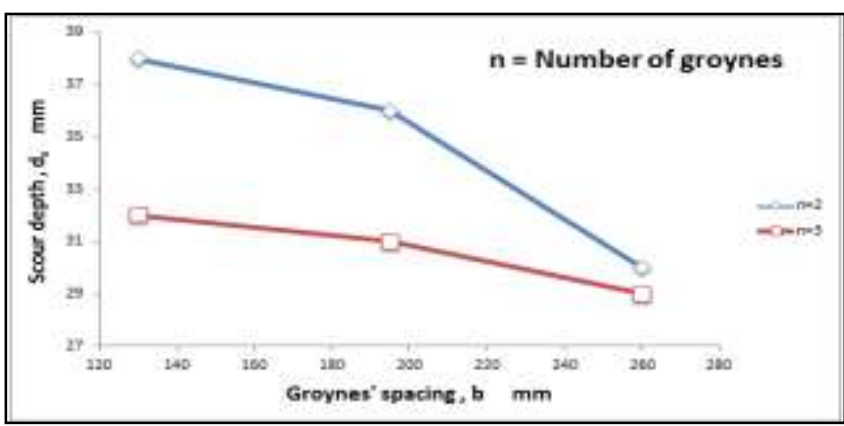

Fig. 11: Effect of groynes' distances on scour depth development

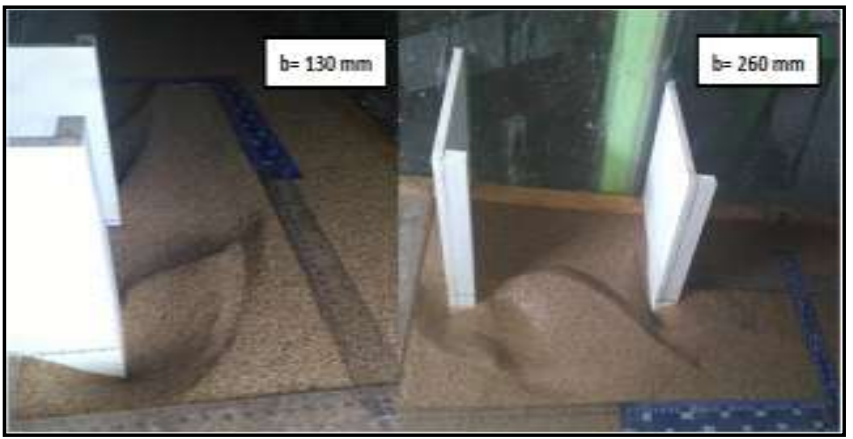

Photo 4: Effect of groynes' distances on scour depth development

Both the figure and the plate show clearly the decrease of scour depth that takes place when the distance between the groynes increased (within the limitation of this study). Increasing spacing by half of groyne length $(0.5 \mathrm{~L})$ will decrease the scour depth by about $3.13-17 \%$.

\section{Development of new formula}

Using the dimensional analysis technique, the scour depth is related to some variables in non-dimensional formula:

$\mathrm{ds} / \mathrm{y}=\mathrm{F}(\mathrm{V} / \mathrm{Vc}, \mathrm{Fr}, \mathrm{n}, \mathrm{b} / \mathrm{y})$

The critical velocity found through semi-logarithmic average velocity equation which based on the velocity profile:

$$
\mathrm{V} / \mathrm{V} * \mathrm{c}=5.75 \log \left(5.53\left(\mathrm{y} / \mathrm{d}_{50}\right)\right)
$$

The following equations are used to find the critical shear velocity
$\mathrm{V} *_{\mathrm{c}}$ where these equations consider modification to Shields diagram:

$$
\begin{array}{ll}
\mathrm{V} *_{\mathrm{c}}=0.0115+0.0125\left(\mathrm{~d}_{50}\right)^{1.4} & 0.1 \mathrm{~mm}<\mathrm{d}_{50}<1 \mathrm{~mm} \\
\mathrm{~V} *_{\mathrm{c}}=0.0305\left(\mathrm{~d}_{50}\right)^{0.5}+0.0065 \mathrm{~d}_{50} 0^{-1} & 1 \mathrm{~mm}<\mathrm{d}_{50}<100 \mathrm{~mm}
\end{array}
$$

The results of the experimental work used as input data in the computer package (IBM Statistics SPSS 16.0) to develop equation utilized to calculate the relative scour depth (ds/y), through a non-linear regression analysis.

$\mathrm{ds} / \mathrm{y}=\mathrm{C}_{1}+\left\{\mathrm{C}_{2} *(\mathrm{~b} / \mathrm{y})\right\}-\left\{\mathrm{C}_{3} *\left(\mathrm{Fr}^{\mathrm{C} 4}\right)\right\}+\left\{\mathrm{C}_{5} *\left(\mathrm{~V} / \mathrm{V}_{\mathrm{C}}{ }^{\mathrm{C} 6}\right) *\left(\mathrm{n}^{\mathrm{C} 7}\right)\right\}$

$$
\begin{array}{llll}
\mathrm{C}_{1}=-1.293 & \mathrm{C}_{2}=-0.035 & \mathrm{C}_{3}=99.281 & \mathrm{C}_{4}=4.452 \\
\mathrm{C}_{5}=9.821 & \mathrm{C}_{6}=2.753 & \mathrm{C}_{7}=-0.043 &
\end{array}
$$

The above formula has a coefficient of determination $\left(\mathrm{R}^{2}\right)$ equal to (0.941). After the simplification and arrangement, the formula becomes:

$\mathrm{ds} / \mathrm{y}=-1.3-\{0.035 *(\mathrm{~b} / \mathrm{y})\}-\left\{99.3 *\left(\mathrm{Fr}^{4.45}\right)\right\}+\left\{9.8^{*}\left(\mathrm{~V} / \mathrm{V}^{2.75}\right) *(\mathrm{n}\right.$ $\left.\left.{ }^{0.04}\right)\right\}$

To test the accuracy of the above formula, $20 \%$ from the original data (that were not used in deriving the above formula) have been substituted in the formula itself, and a statistical comparison between the predicted values of ds/y and the observed values of ds/y were made. The coefficient of determination value $\left(R^{2}=0.903\right)$, reflecting a good agreement for all data, as illustrated in Fig. 12.

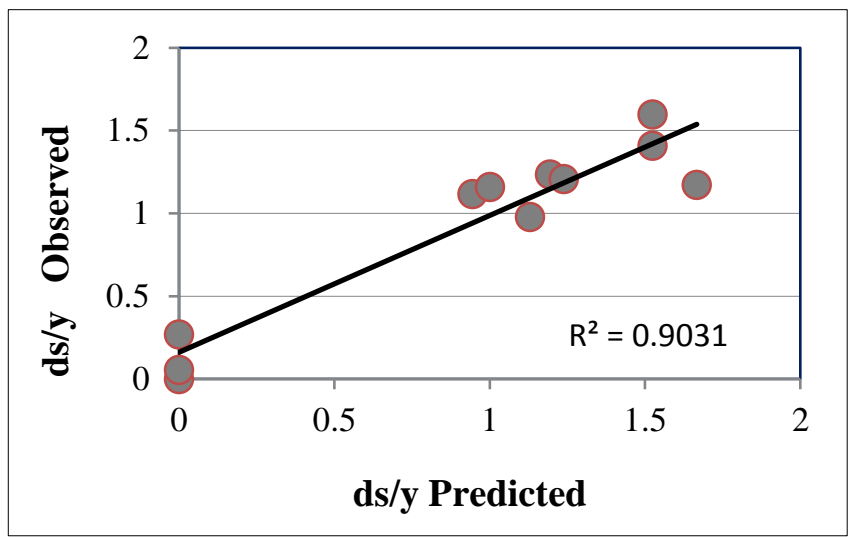

Fig. 12: The formula 3 comparison with the experimental data

\section{Conclusions}

Based on the previous analysis of the experimental work, the following conclusions are drawn:

1- For constant number of groynes and distances between them, the scour depth increased with increasing the flow depth, flow velocity and Froude number.

2- For constant hydraulic conditions, the scour depth decreased with increasing the number of groynes by about $3.33-30.2 \%$ for each increasing in number of groynes equal to one, and the distances between them by about $3.13-17 \%$ for each half of groyne length $(0.5$ L) increase in these distances (within the limitation of this work). 3- The ultimate depth of scour was occurred at the groyne nose from the upstream side.

4- Maximum scour has been observed to occur at the first groyne due to its location, as the first one that the water to collide with.

\section{The list of notations}

b: The distance between groynes (L).

ds: The local scour around groynes (L).

$\mathrm{d}_{50}$ : The main diameter of the sediment particle (L).

Fr: Froude number $(\mathrm{Fr}=\mathrm{V} / \mathrm{Vg}$ y) (-).

$\mathrm{g}$ :The gravitational acceleration $\left(\mathrm{LT}^{-2}\right)$. 
L: The length of groyne (L).

$\mathrm{n}$ : The number of groynes (-).

$\mathrm{V}$ : The mean velocity of the flow $\left(\mathrm{LT}^{-1}\right)$.

Vc: The critical velocity $\left(\mathrm{LT}^{-1}\right)$.

$\mathrm{V} * \mathrm{c}$ : The critical shear velocity $\left(\mathrm{LT}^{-1}\right)$

y: The flow depth (L).

\section{References}

[1] Al-Yassiry, H. H., (2015), "Investigation of Local Scour around Curved Groynes", unpublished M.Sc. Thesis, Civil Department, Faculty of Engineering, University of Kufa, Iraq.

[2] Attia, K., and El Saied, G., (2006), "The Hydraulic Performance of Oriented Spur Dike Implementation in Open Channel", Journal of International Water Technology Conference, IWTC, Alexandria, Egypt, No.10, pp.281-298.

[3] Dawood, A. M., (2013), "A study of Scour and Deposition around Groynes", unpublished M.Sc. Thesis, Civil Department, Faculty of Engineering, University of Kufa, Iraq.

[4] Ghoma, M., I., (2011), "The Effect of wall jet flow on local scour hole Development", unpublished Ph.D. Thesis, School of Engineering Design and Technology, University of Bradford.

[5] Heidarpour, M., Khodarahmi, Z., and Mousavi, S., F., (2003), "Control and reduction of local scour at bridge pier groups using slot". Proceedings, XXX IAHR Congress", Thessaloniki, Greece, August 24-29, 7 pages.

[6] Jafari, B., and Masjedi, A., (2015), "The effect of slot on scouring around spur dike at 180 degree bend", Journal of Advances in Environmental Biology, Vol. 9, No. 5, P.P. 215-219

[7] Kang, J., Yeo, H., and Kim, S., (2011), "Experimental study on the flow characteristics around the refraction groyne", Journal of Scientific Research Engineering, Vol.3, No.8, PP.842-850. Published Online August, 2011, available online: (http://www.SciRP.org/journal/eng).

[8] Lagasse, P. F., and Richardson, E. V., (2001), "ASCE compendium of stream stability and bridge scour papers", Journal of Hydraulic Engineering, ASCE, Vol.127, No.7, pp.531-533.

[9] Raudkivi, A., J., and Ettema, R., (1983), "Clear-water scour at cylindrical piers", Journal of Hydraulic Engineering, ASCE, Vol. 109, No. 3, P.P. 50-338

[10] Toro-Escobar, C., Voigt Jr, R., Melville, B., Chiew, M. and Parker, G., (1998), "Riprap performance at bridge piers under mobile-bed conditions", Transportation Research Record, No.1647, P.P. 27-23.

[11] Zhang, H., and Nakagawa, H., (2008), "Scour around Spur Dyke: Recent Advances and Future Researches", Annuals of Disas. Prev. Res. Inst., Kyoto University, No.51 B, pp.633-652. 